\title{
Water Pollution of Irrigation Ponds in Kagawa Prefecture and Possible Alleviation by Increasing the Amount of Water
}

\author{
Haruo UCHIDA*, Hisayoshi INOUE and Masatoshi HOSOKAWA \\ Department of Hilly Agriculture, Shikoku National Agricultural Experiment Station \\ (2575 Ikano-cho, Zentsuji, Kagawa 765-0053, Japan)
}

\begin{abstract}
We analyzed the degree of pollution of the water in irrigation ponds in part of Kagawa prefecture and simulated the amount of nitrogen in water to evaluate the beneficial effect of dredging and excavation of the ponds. The average values of TN (Total Nitrogen), COD (Chemical Oxygen Demand) and TP (Total Phosphorus) throughout the period of analysis in 3 ponds exceeded the criteria values of irrigation water for paddy fields and the average values of the $\mathrm{pH}$ in all the ponds were also above those of the criteria. Moreover, a considerable degree of eutrophication was observed in 2 of 3 ponds which showed a high average chemical index. In the case of the $\mathrm{pH}, \mathrm{COD}, \mathrm{TN}$ and TP, 90, 58, 50 and $49 \%$ of all the water samples showed values above those of the criteria, respectively, while in the case of DO (Dissolved Oxygen), SS (Suspended Solids) and EC (Electric Conductivity), a small number of samples showed values exceeding those of the criteria. Simulation showed that the concentration of nitrogen in the water decreased by $25 \%$ and $40 \%$ with excavation, resulting in a total volume about 1.5 times as large as that presently. Simulation also showed that the TN concentration of $1.23 \mathrm{mg} / \mathrm{L}$ decreased to $1.13 \mathrm{mg} / \mathrm{L}$, indicating that the TN concentration could be reduced by $10 \%$ without excavation, should the upper pond be excavated.
\end{abstract}

Discipline: Agricultural engineering

Additional key words: total nitrogen, criteria value, simulation, excavation, inflow and outflow

\section{Background}

Kagawa prefecture ranks third for the number of irrigation ponds in Japan and second for the total storage volume. Moreover, the density of the ponds per $\mathrm{km}^{2}$ is highest in the country. Even after the construction of Kagawa-yosui irrigation canal in 1978, 51\% of agricultural irrigation water in the area still depends on local ponds ${ }^{3}$. Irrigation ponds are very important facilities for local agriculture presently. On the other hand, water in the agricultural ponds in the prefecture became polluted after the 1950s along with the development of the Japanese economy. In spite of many administrative measures including regulations to purify the water, it is considered that the degree of water pollution in the ponds is worse than that in the $1950 \mathrm{~s}^{4}$.

In this paper, at first, the authors described the status of water pollution of irrigation water in ponds located in part of Kagawa prefecture. Secondly, they simulated the amount of total nitrogen in the water of the ponds to evaluate the beneficial effect of excavation and/or dredging.

\section{Method for survey and analysis}

Fig. 1 shows a schematic representation of the surveyed area and distribution of irrigation ponds with canals and 2 rivers. Positions where water samples were gathered for chemical analysis are also denoted by black circles. It is noteworthy that there were considerable differences in size among the ponds except for the mother pond which was the biggest one, namely pond G. For example, the surface area ranged from 3 to 30 ha and the storage volume from 200,000 to $1,000,500 \mathrm{~m}^{3}$. And it should also be mentioned in relation to water pollution that fish are cultured with artificial feed in the D and F ponds but without feed in pond $\mathrm{C}$.

The authors sampled water in 11 areas, except for the mother pond, 8 times from May to November, 1999 and analyzed the amounts of TN (Total Nitrogen), COD 


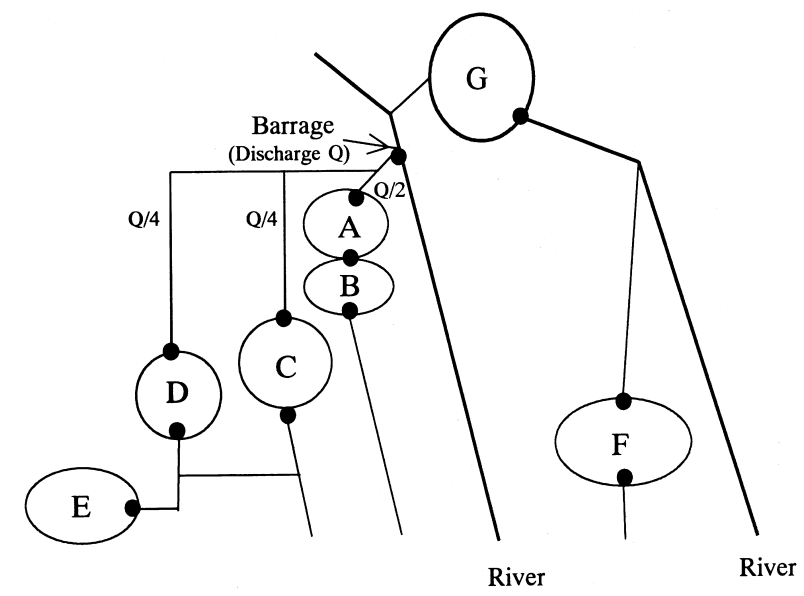

Fig. 1. Distribution of surveyed ponds

(Chemical Oxygen Demand), SS (Suspended Solids), and TP (Total Phosphorus) in the laboratory. Moreover, $\mathrm{pH}$, temperature, EC (Electric Conductivity), and amount of DO (Dissolved Oxygen) were also measured weekly in all the areas, including the mother pond, using simple instruments during the same period.

\section{Pollution of irrigation water}

Table 1 lists the averaged values of the chemical compounds in the water of the ponds, and the criteria values of irrigation water for paddy fields ${ }^{1}$ are shown in Table 2.

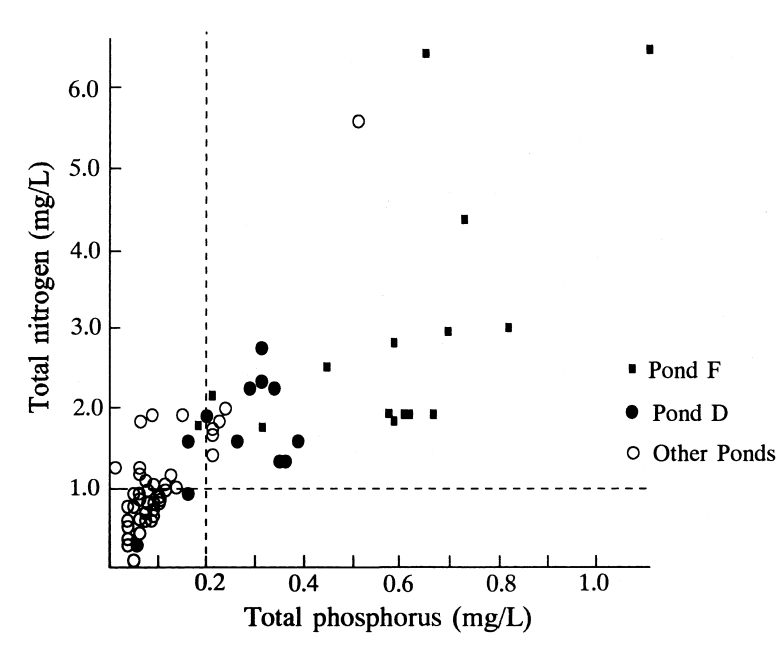

Fig. 2. Relationship between total nitrogen and total phosphorus contents in eutrophic ponds

The average values of TN, COD and TP throughout the period of analysis in the $\mathrm{D}$ and $\mathrm{F}$ ponds exceeded the criteria values. Moreover, a considerable degree of eutrophication was observed in these 2 ponds, which showed high average chemical indices of TN and TP. It appears that the eutrophication of $\mathrm{F}$ had been observed throughout the period of analysis based on Fig. 2 which shows the relationship between TN and TP. As for SS, average values were very low and, moreover, in no cases did they exceed the criteria value of $100 \mathrm{mg} / \mathrm{L}$, and in only 4 samples did the values exceed $50 \mathrm{mg} / \mathrm{L}$ during the

Table 1. Averaged values of chemical components in water

\begin{tabular}{lccccccc}
\hline \hline & $\begin{array}{c}\mathrm{TN} \\
(\mathrm{mg} / \mathrm{L})\end{array}$ & $\begin{array}{c}\mathrm{COD} \\
(\mathrm{mg} / \mathrm{L})\end{array}$ & $\begin{array}{c}\mathrm{SS} \\
(\mathrm{mg} / \mathrm{L})\end{array}$ & $\begin{array}{c}\mathrm{TP} \\
(\mathrm{mg} / \mathrm{L})\end{array}$ & $\mathrm{pH}$ & $\begin{array}{c}\mathrm{EC} \\
(\mu \mathrm{S} / \mathrm{m})\end{array}$ & $\begin{array}{c}\mathrm{DO} \\
(\mathrm{mg} / \mathrm{L})\end{array}$ \\
\hline Mother pond, G & - & - & - & - & 8.37 & 98 & 8.21 \\
Barrage & 0.82 & 3.4 & 4.8 & 0.05 & 7.82 & 159 & 9.11 \\
A in & 1.04 & 4.9 & 12.6 & 0.13 & 8.00 & 168 & 8.83 \\
A out & 0.75 & 5.3 & 6.2 & 0.08 & 8.56 & 150 & 9.04 \\
B out & 0.83 & 5.7 & 5.0 & 0.06 & 8.79 & 156 & 9.64 \\
C in & 1.54 & 14.2 & 21.6 & 0.16 & 9.60 & 134 & 10.94 \\
C out & 1.01 & 8.9 & 10.7 & 0.14 & 9.64 & 135 & 10.46 \\
D in & 1.57 & 7.8 & 24.3 & 0.23 & 7.74 & 165 & 7.72 \\
D out & 1.75 & 11.9 & 13.7 & 0.27 & 8.32 & 157 & 8.96 \\
E out & 0.97 & 8.7 & 8.2 & 0.06 & 8.62 & 216 & 9.17 \\
F in & 2.76 & 13.3 & 20.5 & 0.55 & 8.50 & 191 & 9.15 \\
F out & 2.98 & 21.1 & 25.4 & 0.59 & 8.54 & 195 & 8.41 \\
Average & 1.46 & 9.6 & 13.9 & 0.21 & 8.54 & 160 & 9.13 \\
\hline
\end{tabular}

A, C, D, F in: Inflow of ponds A, C, D and F.

A, B, C, D, E, F out: Outflow of ponds A, B, C, D, E and F.

TN: Total Nitrogen, COD: Chemical Oxygen Demand, SS: Suspended Solids,

TP: Total Phosphorus, EC: Electric Conductivity, DO: Dissolved Oxygen.

Sampling times: TN, COD, SS, TP=8; $\mathrm{pH}, \mathrm{EC}, \mathrm{DO}=26$. 
Table 2. Criteria values of irrigation water and ratio of unacceptable samples

\begin{tabular}{llc}
\hline \hline Item & \multicolumn{1}{c}{ Criteria value } & Unacceptable samples (\%) \\
\hline $\mathrm{pH}$ & $6 \sim 7.5$ & $90(8.54)$ \\
$\mathrm{COD}$ & less than $6 \mathrm{mg} / \mathrm{L}$ & $58(9.60 \mathrm{mg} / \mathrm{L})$ \\
$\mathrm{TN}$ & less than $1 \mathrm{mg} / \mathrm{L}$ & $50(1.46 \mathrm{mg} / \mathrm{L})$ \\
$\mathrm{TP}$ & less than $0.2 \mathrm{mg} / \mathrm{L}$ & $49(0.21 \mathrm{mg} / \mathrm{L})$ \\
$\mathrm{DO}$ & more than $5 \mathrm{mg} / \mathrm{L}$ & $1(9.13 \mathrm{mg} / \mathrm{L})$ \\
$\mathrm{SS}$ & less than $100 \mathrm{mg} / \mathrm{L}$ & $0(13.9 \mathrm{mg} / \mathrm{L})$ \\
$\mathrm{EC}$ & less than $300 \mu \mathrm{S} / \mathrm{m}$ & $0(160 \mu \mathrm{S} / \mathrm{m})$
\end{tabular}

TN: Total Nitrogen, COD: Chemical Oxygen Demand, SS: Suspended Solids, TP: Total Phosphorus, EC: Electric Conductivity, DO: Dissolved Oxygen. Numbers in parentheses denote the average value. Sampling times: TN, COD, SS, $\mathrm{TP}=8 ; \mathrm{pH}, \mathrm{EC}, \mathrm{DO}=26$.

observation period. The average values of EC and DO were also acceptable. On the other hand, the average values of the $\mathrm{pH}$ in all the ponds including the mother pond which was not polluted because of its upper location were above those of the criteria. Since high $\mathrm{pH}$ values appeared throughout the observation period, even before the high temperature season and after the low temperature season, it is conceivable that some factors, except for the temperature, contributed to the increase of the $\mathrm{pH}$ values. Suitable $\mathrm{pH}$ values for many crops extend between neutrality and low acidity, for example, since $\mathrm{pH}$ values from 5.0 to 6.5 are suitable for paddy $^{2}$, high $\mathrm{pH}$ values could damage the crops in the area.

Table 2 shows the criteria values of irrigation water for paddy fields and the percentage of the water samples with values below those of the standard ones (with average values in parentheses). In the case of the $\mathrm{pH}, \mathrm{COD}$,
TN and TP, 90, 58, 50 and $49 \%$ of all the water samples showed values above those of the criteria, respectively, while in the case of DO, SS and EC, a small number of samples showed values exceeding those of the criteria. It is noteworthy that considerably high $\mathrm{pH}$ values were observed throughout the surveyed period, which is one of the characteristics of agricultural irrigation water in the area.

Fig. 3 shows the TN values of the inflow and outflow of the $\mathrm{C}$ and $\mathrm{D}$ ponds where fish were cultured. Here, since pond D was drained in October, data were not presented after September. The outflow was more polluted than the inflow in pond D where artificial feed was used for fish culture. On the other hand, there was no appreciable difference until August between the TN concentration of the inflow and the outflow in pond $\mathrm{C}$ where fish were cultured without feed. The fact that the inflow was more polluted than the outflow in pond $\mathrm{C}$ after August indicates that the purification function of the pond recovered with the decrease of the temperature. The higher level of pollution of the outflow compared with that of the inflow was also observed in pond $\mathrm{F}$ where artificial feed was used for fish culture. Consequently, it is concluded that fish culture with artificial feed polluted the water in the pond.

\section{Simulation of water purification}

Some ponds in the surveyed area were scheduled to be excavated and/or dredged. In this chapter, the authors determined how much the concentration of total nitrogen in the water of the pond should decrease to evaluate the beneficial effect of excavation and/or dredging of the pond using a simulation method. Target ponds included

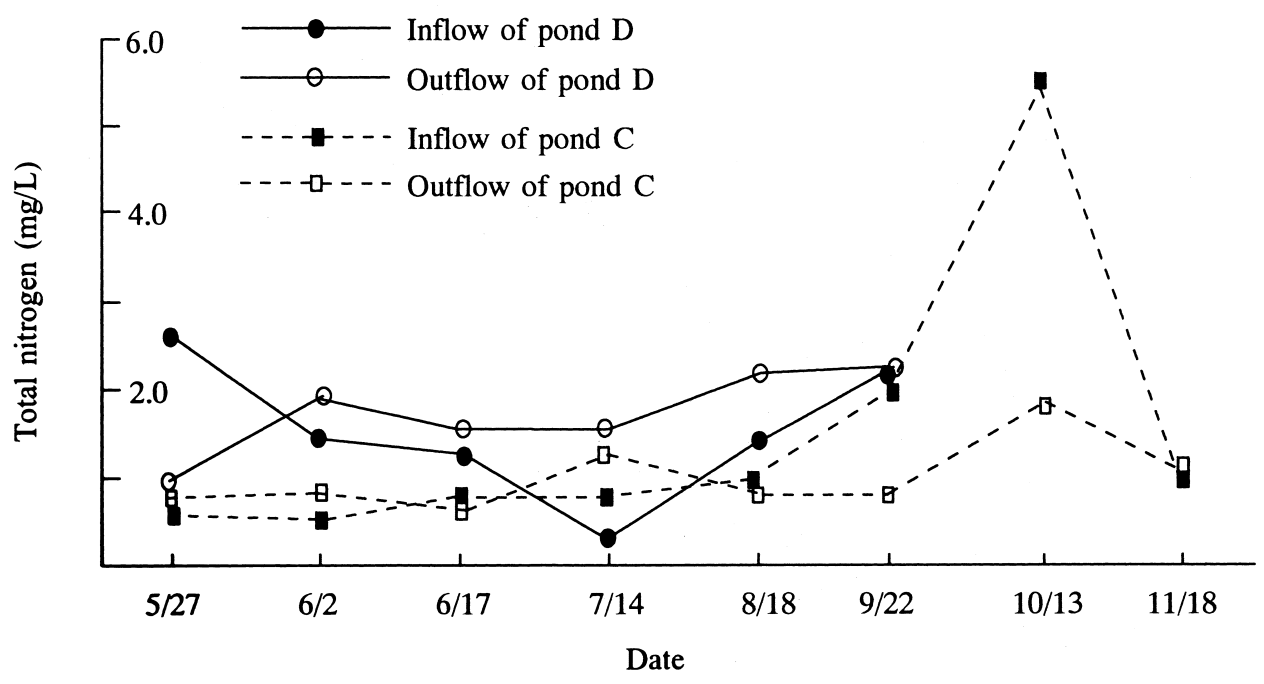

Fig. 3. Total nitrogen content of inflow and outflow water of ponds with fish culture 


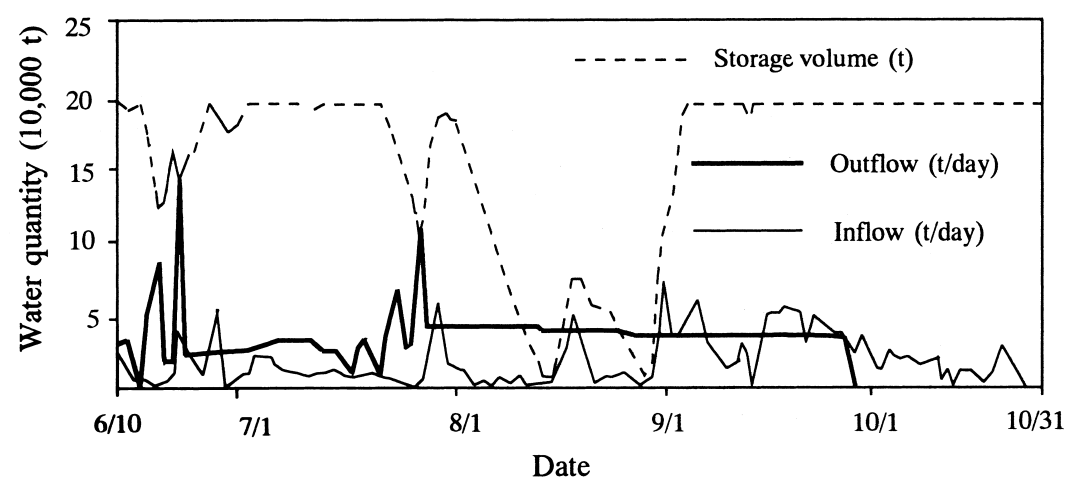

Fig. 4. Calculated inflow, outflow and storage volume (pond A)

ponds $A$ and $D$, both of which were scheduled to be excavated and pond $B$ for which plans for excavation were not made but which might be influenced by the excavation of pond A.

\section{Basic equation for simulation}

The following equation was used to calculate the concentration of total nitrogen in the water at the outlet of a pond.

$$
\mathrm{C}_{\mathrm{pn}}=\left(\sum_{\mathrm{i}=\mathrm{m}}^{\mathrm{m}} \mathrm{C}_{\mathrm{i}} \mathrm{Q}_{\mathrm{i}} / \mathrm{N}+\mathrm{C}_{\mathrm{pn}-1} \mathrm{~V}_{\mathrm{n}-1}\right) / \mathrm{V}_{\mathrm{n}}
$$

Here $\mathrm{m}=1$ when $\mathrm{n} \leqq \mathrm{N}$ or $\mathrm{m}=\mathrm{n}+\mathrm{N}+1$ when $\mathrm{n}>\mathrm{N}$

$$
\text { and } \mathrm{V}_{\mathrm{i}}=\mathrm{V}_{\mathrm{i}-1}+\mathrm{R}_{\mathrm{i}}-\mathrm{E}_{\mathrm{i}}+\mathrm{Q}_{\mathrm{i}}-\mathrm{Q}_{\text {out.i }}
$$

$\mathrm{C}_{\mathrm{pn}}$ : concentration of nitrogen in outflow water $(\mathrm{mg} / \mathrm{L})$, $\mathrm{C} i$ : concentration of nitrogen in inflow water $(\mathrm{mg} / \mathrm{L}), \mathrm{N}$ : presence of water in the pond (days), Qi: inflow volume (t/day), Qout.i: outflow volume (t/day), Vi: storage volume $(\mathrm{t}), \mathrm{R}_{\mathrm{i}}$ : rainfall $(\mathrm{t})$, Ei: evaporation $(\mathrm{t})$.

In Equation (1), it is assumed that $1 / \mathrm{N}$ amount of the daily inflow water would be mixed in one day in the pond and the pond would be full when the calculation started. Simulation started from June 10 when puddling of the paddy field was initiated. For the initial conditions, the measured TN value in each pond on about June 10 was denoted by $\mathrm{C}_{\mathrm{p} 0}$ and the maximum storage volume of each pond by $\mathrm{V}_{0}$.

\section{Data used}

Inflow discharge of each pond was assumed to be distributed, as shown in Fig. 1, based on the daily recorded discharge supplied from the barrage. Since pond A was connected to pond B directly, the inflow discharge of pond A was twice as large as that of ponds $\mathrm{C}$ and $\mathrm{D}$. Daily rainfall and evaporation data recorded at Shikoku
National Agricultural Experiment Station were used to calculate the water balance based on Equation (2).

Daily water requirement in proportion to the irrigated area of each pond was calculated using the distribution of the puddling date in the area and measured water requirement in depth based on 5 growing stages of paddy, respectively. Puddling of paddy fields in the area started from June 10 and continued until June 19 and it was assumed that irrigation, namely the outflow from ponds, would continue for 102 days after puddling in every paddy field. Fig. 4 shows the calculated daily discharge of the inflow and the outflow, and daily storage volume in the case of pond A.

Daily concentration of total nitrogen of the inflow to the A, C and D ponds was calculated, respectively using the regression equation of the monthly surveyed values of the concentration of total nitrogen and recorded discharge in the canal near the barrage. The relationship between these 2 variables was represented by a parabola with a peak.

\section{Fitness of the estimation}

Presence of the inflow in a pond which was

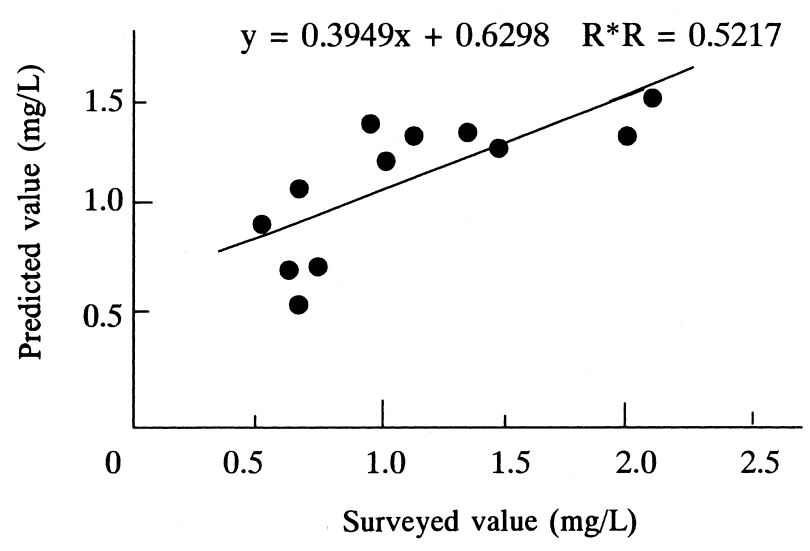

Fig. 5. Surveyed and predicted value of total nitrogen 


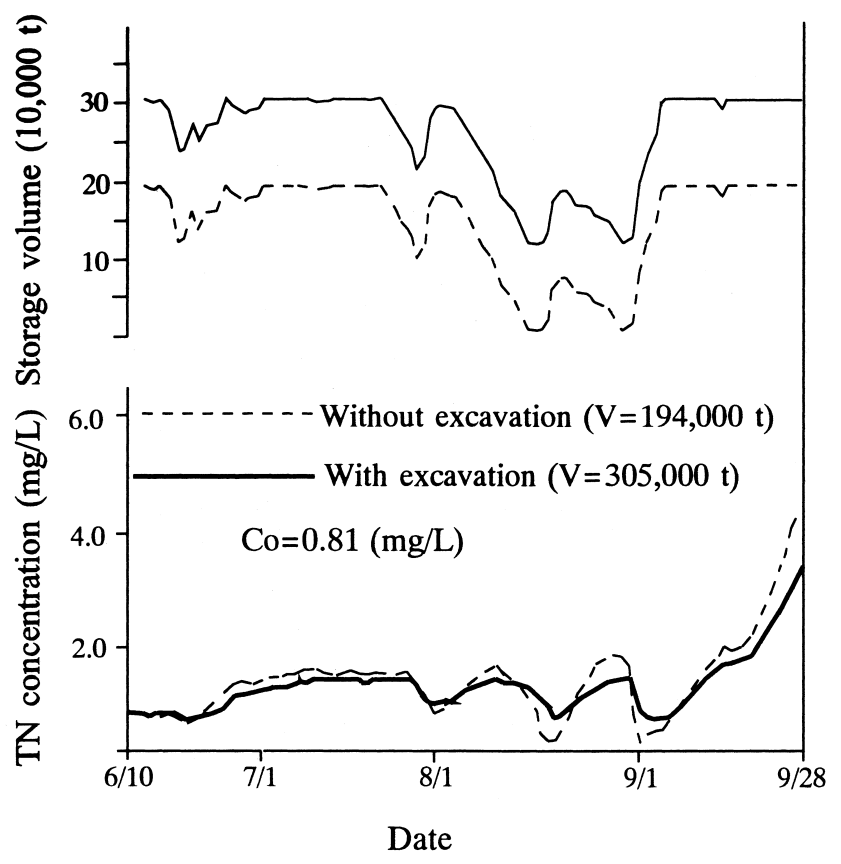

Fig. 6. Simulation results for pond A

described as $\mathrm{N}$ days in Equation (1) was determined so as to minimize the balance of surveyed and simulated values of the TN concentration using the least square method. Fig. 5 shows the relationship between these 2 variables. The coefficient of correlation was 0.72 and the precision of simulation was acceptable.

\section{Results of simulation}

Pond A was scheduled to be excavated for increasing the storage volume. By excavation, the volume would increase to $111,000 \mathrm{t}$ and the total volume would become 1.5 times as large as that presently. Fig. 6 shows the concentration of TN during the irrigation period with (after) and without (before) excavation. The TN concentration with excavation was lower than that without excavation as a whole. At the end of the irrigation period, when the balance reached a maximum level, the TN concentration of $4.27 \mathrm{mg} / \mathrm{L}$ decreased to $3.19 \mathrm{mg} / \mathrm{L}$, indicating that the TN concentration could be reduced by about $25 \%$ by excavation.

The TN concentration in pond $\mathrm{B}$ also decreased during the irrigation period as shown in Fig. 7 although pond $\mathrm{B}$ was not scheduled to be excavated. This is because the direct inflow from pond A, which would be purified by excavation, as described above, led indirectly to a decrease of the TN concentration in the pond. The degree of alleviation was less appreciable than that for the pond which would be excavated directly. The TN concentration of $1.23 \mathrm{mg} / \mathrm{L}$ decreased to $1.13 \mathrm{mg} / \mathrm{L}$, indicating that the concentration of $\mathrm{TN}$ could be reduced by

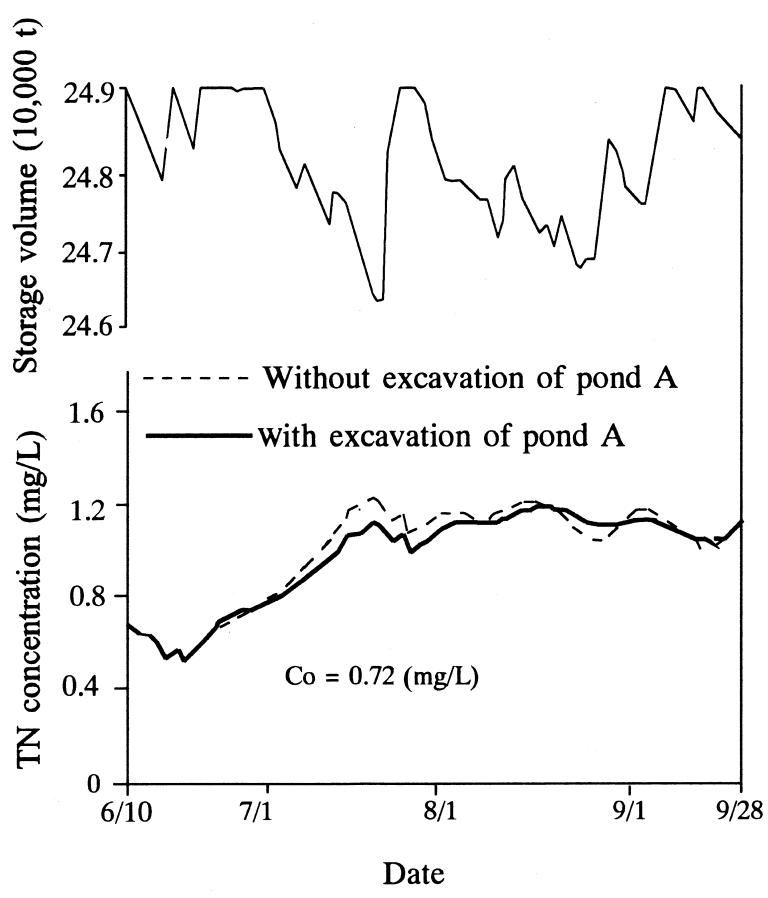

Fig. 7. Simulation results for pond B

$10 \%$ without direct excavation.

Pond D was scheduled to be excavated for increasing the storage volume. By excavation, the volume may increase to $608,000 \mathrm{t}$ and the total volume may become 1.4 times as large as that presently. The efficiency of purification after excavation was high because of the initial large storage volume. Fig. 8 shows that the TN con-

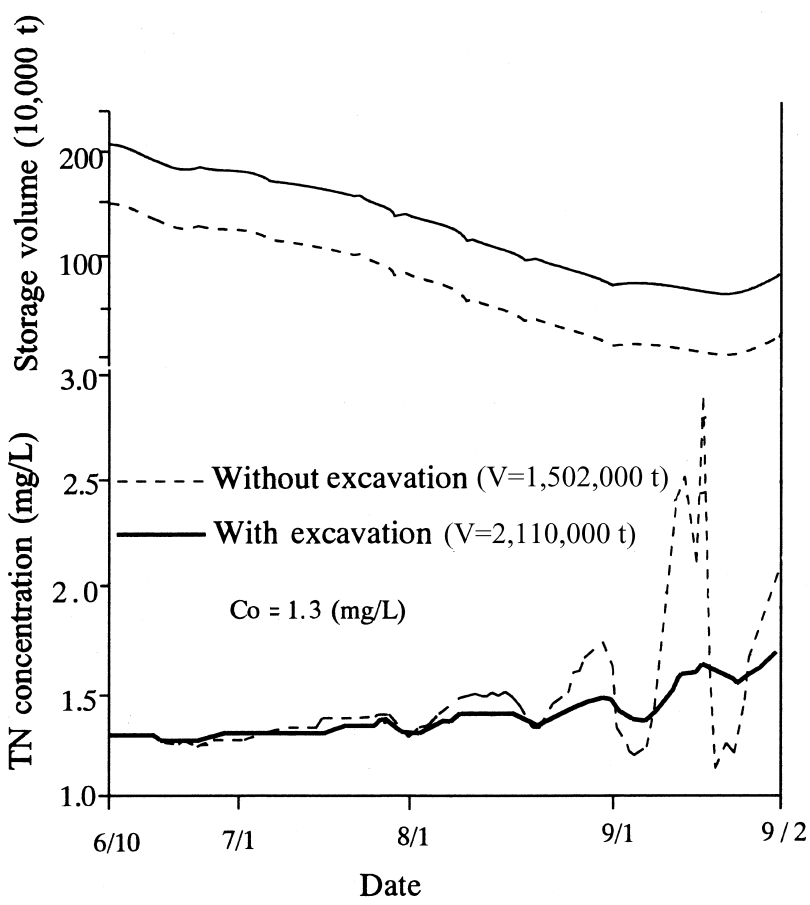

Fig. 8. Simulation results for pond D 
centration of $2.87 \mathrm{mg} / \mathrm{L}$ decreased to $1.64 \mathrm{mg} / \mathrm{L}$, indicating that the concentration of $\mathrm{TN}$ could be reduced by $40 \%$ by excavation.

The TN concentration during the irrigation period could be alleviated by excavation which resulted in the increase of the storage volume and, at the same time, in the decrease in the degree of fluctuation of the TN concentration, as shown in the Figs. It must be noted that the efficiency of alleviation depends not only on the scale of excavation but also on the initial volume of the pond.

\section{Conclusion}

The average values of TN, COD and TP throughout the period of analysis in 3 ponds exceeded the criteria values of irrigation water for paddy fields and the average values of the $\mathrm{pH}$ in all the ponds were also above those of the criteria. Moreover, a considerable degree of eutrophication was observed in 2 of 3 ponds which showed a high average chemical index.

In the case of the $\mathrm{pH}, \mathrm{COD}, \mathrm{TN}$ and $\mathrm{TP}, 90,58,50$ and $49 \%$ of all the water samples showed values above those of the criteria, respectively, while in the case of DO, SS and EC, a small number of samples showed val- ues exceeding those of the criteria.

The outflow was more polluted than the inflow for 2 ponds where artificial feed was used for fish culture. The outflow was not appreciably polluted in a pond where fish were cultured without artificial feed.

Simulation showed that the concentration of total nitrogen in the water decreased by $25 \%$ and $40 \%$ with excavation which resulted in the increase of the total volume by about 1.5 times over that presently. Simulation also showed that the TN concentration of $1.23 \mathrm{mg} / \mathrm{L}$ decreased to $1.13 \mathrm{mg} / \mathrm{L}$, indicating that the concentration of TN could be reduced without direct excavation, should the upper pond connected directly be excavated.

\section{References}

1. Chiba prefecture (1991) Nourin Kougai Pocketbook (Pocketbook for environmental pollution of agriculture and forestry), Chiba, Japan 100-101 [In Japanese].

2. Masujima, H. (1982) Water pollution and plant growth. $J$. JSIDRE, 52 (9), 53-55 [In Japanese].

3. Tada, T. (1996) The role and maintenance of irrigation ponds. Nogyo Kagawa, 48(3),15-16 [In Japanese].

4. Uchida, H. (1998) Water Pollution of Irrigation Pond under Manno-ike and Kagawa-yosui canal Irrigating Area. J. JSIDRE, 66 (1), 69-74 [In Japanese]. 